\author{
壊死型虚血性小腸炎の 1 例 \\ 奥州市総合水沢病院外科 \\ 長谷川 康弘菊池淳 竹村 真一
}

症例は44歳, 男性. 平成14年 1 月に高血圧を指摘され, 以後内服薬で加療されていた。 平成16年 8 月15日より間歇性の腹痛あり, 近医を受診した。鎮痛剤でも症状軽快しない ため, 8 月19日当科紹介, 同日当科入院となった。保存的治療を行い, 一時腹痛の頻度 は減少したが 8 月23日再び強い間歇性の腹痛を認め, 腹部 CT で腹水および右側小腸腸

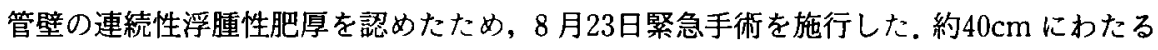
壊死性変化を伴った回腸を認め, 同部位を切除した。病理組織学的骖断で壊死型虚血性 小腸炎と診断された。術後経過は良好で術後 17 病日に退院した。虚血性小腸炎は比較的 稀な疾患であり，術前診断も難しい．本症例でも若年で基礎疾患にそしかったことから 術前には虚血性小腸炎の診断がつかず, 術後に診断が確定した。

索引用語：虚血性小腸炎, 急性腹症

緒言

虚血性小腸炎は比較的稀な疾患であり，診断も一般 的に困難とされている. 今回われわれは比較的若年発 症の壊死型虚血性小腸炎を経験したので，文献的考察 を若干加えて報告する。

$$
\text { 症例 }
$$

患者：44歳, 男性.

主訴: 間歇的腹痛.

既往歴：高血圧症にて平成14年 1 月より内服治療 中.

現病歴：平成16年 8 月15日頃より間歇性の臍周囲痛 が出現し近医を受診し，入院となった．鎮痛剂にて症 状軽快し 8 月17日退院したが，8月18日夕方より再び 腹痛が出現し 8 月19日再度近医を受診した。鎮痛郕で も痛み消失せず,急性腹症の診断にて当科へ紹介され， 救急車にて搬送となった。

入院時現症：身長 $172 \mathrm{~cm}$, 体重 $80 \mathrm{~kg}$, 脈拍60回 $/$ 分, 整. 血圧 $147 / 97 \mathrm{mmHg}$, 体温 $37.2^{\circ} \mathrm{C}$, 眼瞼結膜に貧血 を認めなかった，来院時腹痛は消失しており腹部は平 坦であった。圧痛, 筋性防御を認めなかった。

入院時検查所見 : 白血球 $9,200 / \mathrm{mm}^{3}, \mathrm{CRP} 1.61 \mathrm{mg} /$

2006年 2 月 13 日受付 2006 年 3 月 29 日採用

〈所属施設住所〉

厂023-0053 奥州市水沢区大手町 3-1 $\mathrm{dl}$ と若干の上昇を認めた. GPT $54 \mathrm{IU} / 1$ と軽度肝機能 障害を認めた。その他の検査所見に異常は認めなかっ た。

急性胃腸炎の診断で保存的治療を開始したところ, 腹痛の頻度は減少した。しかし，入院 5 日目に腹痛は 頻度, 程度ともに増悪した。

血液検査所見（8月23日）：WBC $11,500 / \mu 1, C R P$ $2.61 \mathrm{mg} / \mathrm{dl}$ と炎症所見の上昇を認めた.

腹部単純 $\mathrm{X}$ 線写真：拡張した小腸および多量の腸 管ガス像を認めた（図 1 ).

腹部 CT 検査所見: 腹水 (図 $2 \mathrm{a}$ ), 右側小腸の連続 性浮腫性肥厚を認めた（図 2 b).

以上より同部小腸の狭窄性病変によるイレウスの診 断で手術を施行した。

手術所見：開腹時墏液性～腸液様の腹水を中等量認 めた，右側に変色した回腸を認め，これを引き出して 検索したところ，黒褐色調に変色しさらにその肛側に 褐色調の変色を伴う計約 $40 \mathrm{~cm}$ の領域の炎症性変化, 虚血性変化の腸管を認めたため,これを切除した（回 腸末端より口側 $80 \mathrm{~cm}$ の部位から口側約 $45 \mathrm{~cm}$ の腸管 を切除した)。切除腸管の口側腸管は拡張していた。

切除標本所見 : 約 $40 \mathrm{~cm}$ にわたって小腸が黒褐色調 に変色していた，穿孔崔認めなった（図 3).

病理組織学的検査所見: 粘膜下組織から墏膜下組織 にかけて肥厚, 出血, 著明な浮腫を認めた。漿膜下組 


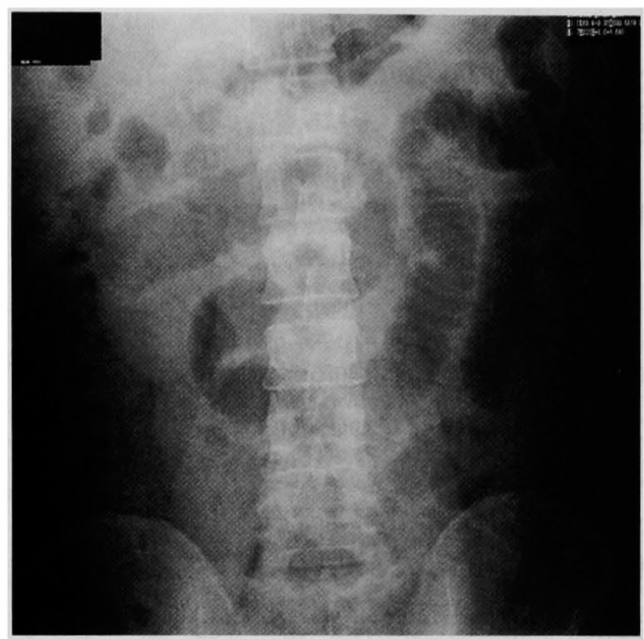

図 1 腹部単純 $\mathbf{X}$ 線検査：拡張した小腸および多 量の腸管ガスを認めた。
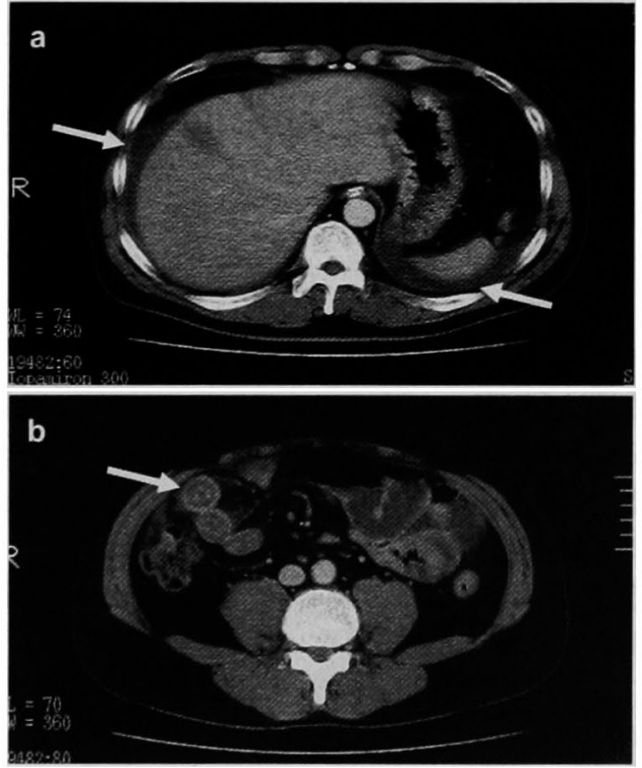

図 2 腹部造影 CT 検査： a ) 腹水を中等量 (矢印) 認めた. b ) 右側小腸の浮腫性肥厚 (矢印) を認め た。

織に好中球を主体とした炎症細胞浸潤を著明に認め た.以上より壊死型虚血性小腸炎と診断された(図 4 ). 術後経過は良好で術後17病日に退院となった。

\section{考察}

小腸では豊富な側副血行路により虚血性病変が発生 しにくいとされている゙1. 虚血性小腸炎の診断は小腸 造影の拇指圧痕像や管状狭窄が特徵とされるが2)31, 大

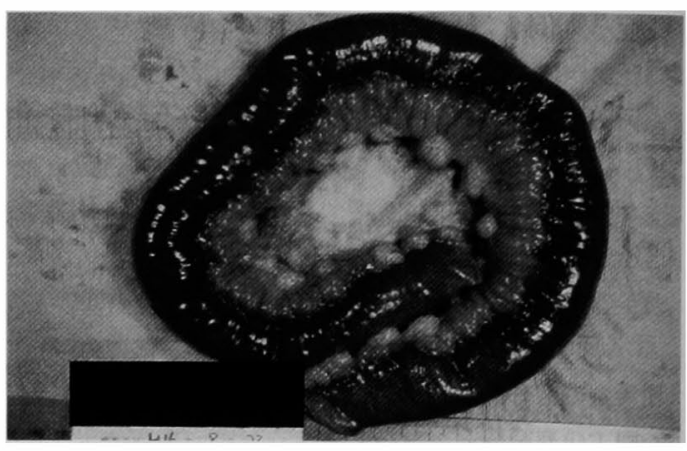

図 3 切除標本写真 : 約 $40 \mathrm{~cm}$ にわたって小腸が黒褐色 調に変色していた，穿孔は認めなかった。

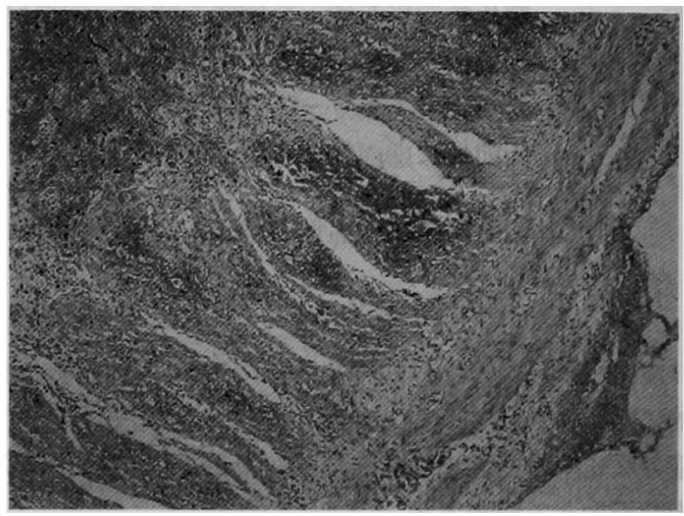

図 4 病理組織学的検査所見 : 粘膜下組織加ら墏膜下組 織にかけて肥厚, 出血, 著明な浮腫を認めた. 槳膜下組 織に好中球を主体とした炎症細胞浸潤を著明に認めた (H. E. 染色 $\times 100)$.

腸に比べて虚血の急性期に起こる著明な炎症と浮腫を あらわす拇指圧痕像を認める機会は少ない21.これは 小腸疾患の頻度が上部消化管や大腸に比べて少なく, 小腸の検查がこれら他部位の病変を否定した後に行わ れる傾向があり，急性病変が見逃されやすいためと考 えられる4!.

虚血性小腸炎は発症時に広範囲に生じた病変でも経 過とともに大部分が修復され一部のみ狭窄をきたすこ とから, 急性期の一過性病変と慢性期の狭窄型病変に 分類される115). 本症例は発症から 8 日であり, 比較的 広範囲の病変であることから急性期病変と考えられ た. 虚血性小腸炎の発症年齢は60歳前後の高齢の男性 に多く ${ }^{5 / 6)}$, 臨床症状は急性期に腹痛や嘔吐, 慢性期に イレウス症状や体重減少が多い, 臨床経過は, 急性期 症状は数日から数週間ほどで軽快し，その後狭窄症状 
が出て慢性期に移行する.

虚血性小腸炎の誘因として糖尿病, 心不全, 脱水, ショック, 不整脈などの全身的要因, 動脈硬化, 血管 炎などの局所的要因がある7. 一方, 基硞疾患の存在し ない報告もある8). 本症例では高血圧の既往を認めた が, 44歳と若年であり, 病理組織学的検査でも動脈硬 化像は認めなかったことから, 基礎疾患との関連の可 能性は低いと考えられた。

病理組織学的には粘膜下層を中心とする線維化, 炎 症細胞浸潤, 血管に富む肉芽組織, 血管の肥厚, リン 八゚管肥厚, 浮腫が挙げられる”. 本症例では粘膜下組織 から整膜下組織にかけて肥厚, 出血, 著明な浮腫を, 槳膜下組織に好中球を主体とした炎症細胞浸潤を著明 に認め，虚血性小腸炎に矛盾しない結果であった。

虚血性小腸炎の診断は困難とされているが壊死性虚 血性小腸炎は腹部所見の增悪, $\mathrm{CT}$ 椧査上腹水を認め, 試験穿刺により血性腹水を認め診断したとの報告があ る9!. 本症例では術前に虚血性小腸炎の診断がつかな かったが, 腹部所見が増悪し, 腹部 CT で腹水および 右側小腸の限局性の浮腫性肥厚を認めたため緊急手術 を施行した，最近では，虚血性小腸狭窟に対し，腹腔 鏡補助下手術が行われ，いずれも術後経過良好な症例 が報告されている ${ }^{610111}$. 本症例は狭窄型虚血性小腸炎 ではなかったが, 術前診断の困難な本疾患に対し腹腔 鏡的アプローチは低侵襲であり, 観察, 診断の面でも 有効と思われた.

\section{結語}

今回われわれは比較的若年発症の虚血性小腸炎を経 験した。急性腹症の原因としては稀だが，虚血性小腸 炎も念頭におく必要があると思われた。

謝辞

本症例の病理学的診断に御指迺いただきました，岩手医 科大学病理学第 2 講座教授, 增田友之先生に深謝申し上げ ます。

\section{文献}

1）岩下明徳，八尾隆史, 飯田三雄他：虚血性小腸狭 悎（狭䇤型虚血性小腸炎）の臨床病理学的検索. 胃と腸 25:557-569，1990

2）古賀秀樹, 飯田三雄, 八尾隆史他：消化管虚血性 疾患の比較診断学. 胃と腸 $35: 1591-1601,2000$

3）松本主之, 檜沢一興, 中村昌太郎他：小腸の非腫 瘍性疾患におけるX線検查の有用性. 胃と腸 38:1005-1016, 2003

4) 勝又伴栄, 岡部治弥, 中 栄男: 虚血性小腸狭窄 の臨床的および病理組織学的研究. 日内会誌 $72: 1658-1671,1985$

5）飯田三雄, 岩下明徳, 松井敏幸 他：虚血性小腸炎 15例の臨床像およびX線像の分析. 胃と腸 25 ： $523-535,1990$

6）東 幸宏, 中村利夫, 林 忠毅他：腹腔鏡補助下 に切除した狭窄型虚血性小腸炎の 1 例. 日臨外会 誌 $65: 1277-1280,2004$

7）江淵義昭, 中野 茂, 三木一正：虚血性小腸炎 (Ischemic Enteritis) 診断と治療を中心に. 診断 と治療 90:1157-1159, 2002

8）板倉 滋, 井上和彦, 坂之上一史他: 発症後比較 的早期に診断できた虚血性小腸炎の 1 例. 島根医 $16: 61-64,1998$

9）鈴木 修,三村耕作，小林正史他：虚血性小腸炎 (狭窄型, 壊死型) 22 例. 日臨外会誌 $62: 410$ $-414,2001$

10）三宅敬二郎，田中 聰，橋本哲明他：腹腔鏡補助 下手術を行った虚血性小腸狭窄の 1 例. 日臨外会 誌 $58: 2562-2565,1997$

11）白石 好, 磯部 紫, 森 俊治他：外偒後の虚血 性小腸狭窄に対する腹腔鏡下補助手術の 1 例。日 臨外会誌 $63: 2458-2462,2002$ 


\title{
A CASE OF NECROSIS TYPE ISCHEMIC ENTERITIS
}

\author{
Yasuhiro HASEGAWA, Jun KIKUCHI and Shinichi TAKEMURA \\ Department of Surgery, Oshu Municipal Mizusawa General Hospital
}

A 44-year-old man who had been medicated for hypertension since January 2002 had intermittent abdominal pain on August 15, 2004. He was referred to the hospital on August 19, because the intermit. tent gastric pain persisted despite medical treatment at another hospital. Conservative therapy resulted in a decrease of frequency of episodes of abdominal pain. However, on August 23, intermittent pain became severe. Multiple deposits of small intestinal gas were present on abdominal X-ray, and ascites and extremely edematous change of the ileum were seen on abdominal CT scan. So emergency operation was performed. At operation, we found about $40 \mathrm{~cm}$ long ischemic or necrotic change of the ileum and partially resected the changed ileum. The histopathological diagnosis was necrosis type ischemic enteritis. The patient's postoperative course was uneventful. He was discharged from the hospital 17 days after the oppration.

Ischemic enteritis of the small intestine is relatively rare and we often have difficulties in preoperative diagnosis. In this case, we could diagnose the disease after the operation. 